JARES, Vol. 3 No. 1 March, 2018; p-ISSN: 2502-826X; e-ISSN: 2503-1163

Copyrights@ Balitar Islamic University, Blitar, Indonesia;

$\mathrm{Http} / / / j a r e s . u n i s b a b l i t a r . w e b . i d$

\title{
EFFECTS OF RICE HUSK ASH AND EGGSHELL ON THE GROWTH AND YIELD OF RED CHILI (Capsicum annuum L.)
}

\author{
Tri Kurniastuti \\ Lectuter of Balitar Islamic University, Blitar \\ Email : kurniastuti5@gmail.com
}

\begin{abstract}
The purpose of this study was to determine the effect of rice husk ash dosage and eggshell on the growth and yield of red chili, and obtain a treatment that gives the best results on fruit red chili plant. The experiment was arranged with Group Random Design (RAK) with factorial design with two factors and three replications, factor $\mathrm{I}$ is dose rice husk ash consists of three levels ie A0: $0 \mathrm{~g} / \mathrm{plant}$, A1: $25 \mathrm{gr} /$ plant, A2: $50 \mathrm{~g} /$ plant, G3: 75gr / plant. The second factor is the dose eggshell consists of 3 levels ie: C0: $0 \mathrm{~g} /$ plant, W1: $15 \mathrm{gr} /$ plant and W2: $30 \mathrm{gr} /$ plant. The experiment will have 9 combination treatment from those 2 factors. The resutls showed that the provision of rice husk ash give the significant effect on height plant growth and the number of leaves, the best dose is the provision of rice husk ash $50 \mathrm{gr} /$ plant. Provision of eggshell give real effect on plant yield of red pepper that is the number of productive branches, number of fruits per plant and fruit weight crop with the best dosage is $30 \mathrm{gr} /$ plant.
\end{abstract}

Keywords: eggshell, red chili, rice husk ash

\section{INTRODUCTION}

Red chili ( Capsicum annuum L.) is a high economically valuablevof vegetables commodity. The need for red chili is increase continuely along with the increase of people in Indonesia. The last few months, the price of red pepper in Indonesia was soared. The increase was caused by minimum supply on the market due to disrupted by several things, such as the low production of pepper plants caused by the weather and crop cultivation factors. The high price of red chilli has not aligned with the profit received by farmers for production input factors such as the price of fertilizers and insecticides that are increasingly expensive.

Lately, use of agricultural waste and livestock serve as alternative to lower the production costs. Agricultural waste which easy to find in Blitar is rice husk ash and eggshell. Farmers using agricultural waste which is easily obtained as alternanif organic fertilizers in order to reduce dependence on fertilizer's organic. Ash from burning rice husk is basically a waste, but it is a source of quite high nutrients. Based on the analysis of rice husk ash carried by Tamtomo, et al (2015), the content of nutrients in the rice husk ash is quite high especially for $\mathrm{P}$ is $0.2107 \%, \mathrm{~K}$ amounted to $0.3979 \%, 0.4758 \%$ is $\mathrm{Ca}$ and $\mathrm{Mg}$ content is $0.0868 \%$. According Setyorini (2003) in Kusuma A, H (2013), rice husk ash has metal binding function. In addition, the rice husk ash serve to loosen the soil, so that it can simplify plant roots to absorb nutrients. Results of Norhasanah's study (2012) showed that the dosage of rice husk ash have very significant effect on all variables, which husk ash dose $48 \mathrm{~g} /$ polybag is the best dose of the vegetative growth of cayenne pepper plant varieties Green Chakra, that is at the variable plant height and number of branches crop. Husk ash dosage of $72 \mathrm{~g}$ / polybag is the best dose to generative growth cayenne pepper plant that is at the variable age of the plant during flowering, and the number of flower planting. 
JARES, Vol. 3 No. 1 March, 2018; p-ISSN: 2502-826X; e-ISSN: 2503-1163

Copyrights@ Balitar Islamic University, Blitar, Indonesia;

$\mathrm{Http} / / /$ jares.unisbablitar.web.id

Eggshells flour contain calcium $(\mathrm{Ca})$ and magnesium $(\mathrm{Mg})$, which can increase the $\mathrm{pH}$ of the soil. According Sundari (2010) in the ES Goddess (2016), egg shells containing nearly $95.1 \%$ consisting of organic salts, $3.3 \%$ organic materials (especially proteins), and $1.6 \%$ water) about $98.5 \%$ and Magnesium carbonate (MgCO Most organic materials consisting of compounds of calcium carbonate $(\mathrm{CaCO})$ about 0.85\%. According Stadelman and Owen (1989) in the Goddess ES (2016) states, the amount of mineral in 2.25 grams egg shell consisting of 2.21 grams of calcium, magnesium 0.02 grams, 0.02 grams of phosphorus and a little iron and sulfur. The results of Nurjayanti (2012) study, the granting of an eggshell flour can be used as a substitute for lime, because it can raise the $\mathrm{pH}$ of alluvial soil and gives the same red chili's yield growth with the addition of compost mixture and flour eggshell. Marita M. M (2013) reported that the use of chicken egg shells with the dose of $8 \mathrm{~g} /$ plant to control fusarium wilt in tomato plants exhibited by some plants can still survive and thrive well in comparison with the control plants. The result of Sham, Z. Z (2014) research reported that giving the egg shell powder at $25 \mathrm{gr} /$ plant can increase soil $\mathrm{pH}$ levels from 4.2 to 6.8 . The waste egg shells can be used as fertilizer because it contains calcium and can enhance the Adenium plant height.

\section{MATERIAL AND METHODS}

The experiment was conducted in Blitar in March until August 2017. The experiment was arranged in a randomized block design (RAK) with factorial design with two factors and three replications, factor I is dose rice husk ash consists of three levels ie A0: $0 \mathrm{~g} / \tan , \mathrm{A} 1: 25 \mathrm{gr} / \mathrm{tan}, \mathrm{A} 2: 50 \mathrm{gr} / \mathrm{tan}, \mathrm{G} 3: 75 \mathrm{gr} / \mathrm{plant}$. The second factor is the dose eggshell consists of three levels ie: C0: $0 \mathrm{~g} / \mathrm{tan}, \mathrm{W} 1: 15 \mathrm{gr} / \tan$ and W2: 30 gr / plant. The experiment will have 9 combination treatment from those 2 factors. Observation of the plant include: plant height, number of leaves per plant, stem diameter, planting fruit number and weight of the fresh fruit crop. Data were analyzed using Analysis of Varian (ANOVA) at 5\%.If there is a real effect between treatment continued with HSD test level of $5 \%$.

\section{RESULTS AND DISCUSSION}

\section{Effect of Rice Husk Ash and Egg Shells on Red Chili Plant High}

The results of analysis of variance (ANOVA) 5\% indicates that there is no interaction between treatment of rice husk ash (A) and the dose of egg shells (C) on the observation of the plant height at all ages, but in treatment of giving rice husk ash at the age of 60 and 80 DAP are a significant effect on plant height. In table 1 shows that treatment with the giving of ash dose of $25 \mathrm{~g} / \mathrm{crop}$ (A1) and $50 \mathrm{~g} / \mathrm{plant}$ (A2), showed that the average of plant heigh is better than without the provision of rice husk ash (A0) at the age of 60 DAP. In the treatment of eggshell is significantly affected plant height at 80 DAP observations. Giving an eggshell with a dose of $30 \mathrm{~g} /$ plant is the best treatment in plant height of $63.35 \mathrm{~cm}$ (Table 1). On treatment of giving rice husk ash and eggshell separately each treatment gives a significant effect on the age of 60 DAP, it is presumably because at the age of 20 DAP and 40 DAP, nutrient content contained in husk ash and eggshell not decompose so that it can not be improve the rooting environment, consequently nutrients can not be absorbed by plants. At the age of 60 and 80 DAP, the giving of husk ash and eggshell separately able to increase plant growth. It is suspected that macro nutrients and micro elements contained in rice husk ash and eggshell already can be used to run the metabolism of plants so that the plants can show better growth than the control. Hardjowigeno (2003) explains that the plant metabolic disorders can be caused by lack of nutrients such as phosphorus that inhibits plant growth. Furthermore, Butcher and Richard 
JARES, Vol. 3 No. 1 March, 2018; p-ISSN: 2502-826X; e-ISSN: 2503-1163

Copyrights@ Balitar Islamic University, Blitar, Indonesia;

$\mathrm{Http} / / /$ jares.unisbablitar.web.id

(2003) explain that not just containing phosphorus as much as $0.3 \%$, eggshell containing micro elements (magnesium, sodium, calcium, zinc, manganese and copper) of $0.3 \%$. Magnesium (Mg) plays an important role in the transport of phosphate in plants. Thus, the phosphate content in plants can be increased by the addition of magnesium through the eggshell.

Table 1. Average of Heigh Plant $(\mathrm{cm})$ at Various Treatment

\begin{tabular}{|c|c|c|c|c|}
\hline \multirow[b]{2}{*}{ Treatment } & \multicolumn{4}{|c|}{ Observation Age } \\
\hline & 20 DAP & 40DAP & 60 DAP & 80 DAP \\
\hline \multicolumn{5}{|l|}{ Rice husk ash } \\
\hline A0 & $9.30 \mathrm{a}$ & $22,03 \mathrm{a}$ & $44,33 \mathrm{a}$ & $61,25 \mathrm{a}$ \\
\hline A1 & $9.54 \mathrm{a}$ & $23.43 \mathrm{a}$ & $51,45 \mathrm{~b}$ & 60,81 a \\
\hline A2 & $10.26 \mathrm{a}$ & $24.09 \mathrm{a}$ & $52,01 \mathrm{~b}$ & $64,86 \mathrm{~b}$ \\
\hline \multicolumn{5}{|l|}{ Eggshell } \\
\hline $\mathrm{C} 0$ & $9.68 \mathrm{a}$ & $26.10 \mathrm{a}$ & $46,71 \mathrm{a}$ & $60,92 \mathrm{a}$ \\
\hline $\mathrm{C} 1$ & $11.87 \mathrm{a}$ & 26,98 a & $50.04 \mathrm{a}$ & $61,87 \mathrm{ab}$ \\
\hline $\mathrm{C} 2$ & $10.91 \mathrm{a}$ & $23.88 \mathrm{a}$ & $51,345 \mathrm{a}$ & $63,35 \mathrm{~b}$ \\
\hline
\end{tabular}

Description: The figure followed by the same letter in the same column showed no significant difference in test HSD 5\%. DAP = days after planting.

\section{Effect of Rice Husk Ash and Eggshell on Total Leaf Red Chili Plant}

Results of analysis of variance (ANOVA) 5\% indicates that there is no interaction between treatment of rice husk ash (A) and the dose of eggshells (C) to the number of leaves in all observation age, but in treatment giving of rice husk ash at the age of 60 and 80 DAP have significant effect on the plant. In Table 2 showed that treatment with the giving of ash in dose of $25 \mathrm{~g} /$ plant (A1) gives significantly different from the treatment of $50 \mathrm{~g} /$ plant (A2) and produce average of number of leaves that are better than without the giving of rice husk ash (A0), that is 217.67. In the treatment of eggshell giving is significantly affected the number of leaves at the age of 80 DAP observations. Giving an eggshell with a dose of $30 \mathrm{~g} / \mathrm{plant}$ is the best treatment result in number of leaves amounted to 224.45 leaves. From the results of Table 2 indicated that the vegetative growth of the plants treated with rice husk ash $50 \mathrm{~g} /$ plant showed better growth in variable plant height and number of leaves, allegedly on dose of $50 \mathrm{~g} /$ plants can improve soil structure and add nutrients so that the vegetative growth of the plant will be better. bAccording to Ali et al. (2012) in Baharudin, R (2016), if the organic material is available, the activity of soil organisms can improve nutrient availability, nutrient cycling, and the formation of soil micro and macro pores. Kusuma, A. H (2013) indicate that the addition of charcoal or rice husk ash in various proportions potentially increased lateral root length and shoot dry weight. Give of eggshell $30 \mathrm{~g} /$ plant showed a better vegetative growth than the control, it is suspected because of the provision of an eggshell $30 \mathrm{gr} /$ plant is enough to add nutrients that plants need. Kastono (2005), explains that along with the increase in nutrients, the growth of vegetative organs also increased, so that it will affect the results. 
JARES, Vol. 3 No. 1 March, 2018; p-ISSN: 2502-826X; e-ISSN: 2503-1163

Copyrights@ Balitar Islamic University, Blitar, Indonesia;

$\mathrm{Http}: / / j a r e s . u n i s b a b l i t a r . w e b . i d$

Table 2.Average of Number of leaves at Various Treatment

\begin{tabular}{|c|c|c|c|c|}
\hline \multirow[b]{2}{*}{ Treatment } & \multicolumn{4}{|c|}{ Observation Age } \\
\hline & 20 DAP & 40 DAP & 60 DAP & 80 DAP \\
\hline \multicolumn{5}{|c|}{ Rice Husk Ash } \\
\hline A0 & $35.76 \mathrm{a}$ & $72,34 \mathrm{a}$ & $131,78 \mathrm{a}$ & $189.90 \mathrm{a}$ \\
\hline A1 & $33.65 \mathrm{a}$ & $76.03 \mathrm{a}$ & $139,45 \mathrm{a}$ & $203.22 \mathrm{ab}$ \\
\hline A2 & $35.12 \mathrm{a}$ & $74.61 \mathrm{a}$ & $145,44 \mathrm{~b}$ & $217,67 \mathrm{~b}$ \\
\hline \multicolumn{5}{|l|}{ Eggshell } \\
\hline $\mathrm{C} 0$ & $34.70 \mathrm{a}$ & $76.75 \mathrm{a}$ & $135,33 \mathrm{a}$ & $201,24 \mathrm{a}$ \\
\hline $\mathrm{C} 1$ & $37.61 \mathrm{a}$ & 72,98 a & $139,25 \mathrm{~b}$ & 208,45 a \\
\hline $\mathrm{C} 2$ & $35.87 \mathrm{a}$ & $73.92 \mathrm{a}$ & $147,36 \mathrm{c}$ & $224,45 \mathrm{~b}$ \\
\hline
\end{tabular}

Description: The figure followed by the same letter in the same column showed no significant difference in test HSD $5 \%$. DAP $=$ days after planting.

\section{Effect of Rice Husk Ash and Eggshell on Red Chili Yield}

Results of analysis of variance (ANOVA) 5\% indicates that there is no interaction between treatment of rice husk ash (A) and the dose of eggshell (C) to the number of productive branches, The number of fruit / plant and weight of fruit / plant (g), but the treatment of rice husk ash are showed the significant effect. In Table 3 showed that treatment with rice husk ash with dose of $25 \mathrm{~g} / \mathrm{crop}$ (A1) and $50 \mathrm{~g} / \mathrm{plant}$ (A2) produces the number of productive branches are better than without the provision of rice husk ash (A0). Treatment rice husk ash with a dose of $50 \mathrm{~g} /$ plant (A2) were significantly different and produce the best productive branch number compared to the treatment giving chaff $25 \mathrm{~g} /$ plant (A1). In the treatment of eggshell significantly affect the number of productive branches. Giving an eggshell with a dose of $30 \mathrm{~g} /$ plant is the best treatment and produce a number of productive branches of 19.12 (Table 3).

Table 3. Number of productive branches, the number of fruit / plant and the weight of fresh fruit / plant

\begin{tabular}{cccc}
\hline Treatment & $\begin{array}{c}\text { Number of productive } \\
\text { branches }\end{array}$ & $\begin{array}{c}\text { Haverst } \\
\text { Number of fruit/plant }\end{array}$ & $\begin{array}{c}\text { Weight of fresh fruit / plant } \\
(\mathbf{g})\end{array}$ \\
\hline Rice Husk Ash & $11.22 \mathrm{a}$ & $19,55 \mathrm{a}$ & $379,23 \mathrm{a}$ \\
A0 & $19,01 \mathrm{~b}$ & $35,21 \mathrm{~b}$ & $390,78 \mathrm{a}$ \\
A1 & $22,45 \mathrm{c}$ & $37,47 \mathrm{~b}$ & $421,32 \mathrm{~b}$ \\
A2 & $16,67 \mathrm{a}$ & $25,81 \mathrm{a}$ & $349,56 \mathrm{a}$ \\
\hline Eggshell & $17,55 \mathrm{ab}$ & $31,63 \mathrm{~b}$ & $401,46 \mathrm{a}$ \\
C0 & $19,12 \mathrm{~b}$ & $35,82 \mathrm{c}$ & $439,34 \mathrm{~b}$ \\
\hline
\end{tabular}

Description: The figure followed by the same letter in the same column showed no significant difference in test HSD $5 \% . \mathrm{DAP}=$ days after planting. 
JARES, Vol. 3 No. 1 March, 2018; p-ISSN: 2502-826X; e-ISSN: 2503-1163

Copyrights@ Balitar Islamic University, Blitar, Indonesia;

$\mathrm{Http} / / /$ jares.unisbablitar.web.id

In Table 3 showed that treatment of rice husk ash was significantly different to the number of fruit / plant. Provision of rice husk ash with a dose of $25 \mathrm{~g} / \mathrm{crop}$ (A1) is not different from rice husk ash treatment dose of $50 \mathrm{gr} /$ plant. This is presumably because rice husk ash can improve soil structure and becomes more crumbs so that root growth is getting better. This is consistent with the results of research Septiawan (2014) that the application of organic manures rice husk ash and compost able to soften the very hard soil aggregates into the ground that is able to bind water longer, so that the land will be stabilized by aeration of soil to be better because the pore space land increases due to the formation of aggregates. Furthermore, according to Nurida (2009) in Septiawan (2014) which stated that the composition of the soil aggregates or fragments of soil affect the growth of roots and canopy, and perhaps eventually to the production of the plant. In the treatment of eggshell also making a significant difference to the number of fruit / plant. The best treatment contained in the giving of the eggshell of $30 \mathrm{~g} /$ plant, and produce the amount of fruit amounting to 35.82 fruit / plant. In Table 3, demonstrated that treatment of rice husk ash with a dose of 50 $\mathrm{g}$ / plant capable to produce the highest fruit weight of $421.32 \mathrm{~g} /$ plant and significantly different compared to the treatment without rice husk ash (A0). Treatment without rice husk ash (A0) is not significantly different from rice husk ash treatment dose of $25 \mathrm{~g} /$ plant. This indicates that the provision of rice husk ash $25 \mathrm{~g} /$ plant has not been enough to increase the number of pieces of red chili plants. Increased fruit weight indicated on rice husk ash dosage $50 \mathrm{~g} /$ plant. This is presumably because Si contained in the rice husk ash can increase the availability of $\mathrm{P}$, by replacing the $\mathrm{P}$ ions bound to the land component with $\mathrm{Si}$ ions, so that P becomes more available. Yulianti C, E (2011) demonstrated that provision rice husk ash can increase the carbon content of silica are available, $\mathrm{P}$-available in the soil. Giving rice husk ash also give good influence on the uptake of Si-plants. The function of Phosphorus $(\mathrm{P})$ is to stimulate root growth, accelerate flowering, seed and fruit ripening. Lingga (2008) adds that, $\mathrm{P}$ element required to reproduce plants generative growth (flower and fruit).

In the treatment of egg shells $30 \mathrm{~g} /$ plant also produces the highest fruit weight and significantly different compared with those without eggshell (C0) and the treatment of eggshell $15 \mathrm{~g} /$ plant $(\mathrm{C} 1)$. The best treatment is contained in the provision of eggshell amounting to $30 \mathrm{~g} /$ plant can produce fruit weight of $439.34 \mathrm{~g}$ / plant. Giving eggshell could be expected to improve the growth and yield, because the eggshell contain macro and micro nutrients required by plants. Butcher and Richard (2003) in Noviansyah, B, et al (2015) states that the eggshell contain as much as $0.3 \%$ phosphorus and contain trace elements (magnesium, sodium, potassium, zinc, manganese and copper) of $0.3 \%$. Phosphorus plays a role in energy transfer in the plant cells, such as ADP and ATP. Additionally, phosphorus acts as the building blocks of nucleic acids (DNA and RNA), lipids and proteins (Agustin, 1990). Phosphorus (P) for plants is useful to stimulate root growth, especially root seeds and young plants. Additionally, phosphorus serves as raw material for the formation of a specific protein; help assimilation and respiration; and accelerate flowering, seeds, and fruit. Calcium (Ca) served to stimulate the formation of root hairs, hardened stems of plants, and stimulates the formation of seeds. The calcium present in the stems and leaves is believed to neutralize the compound or unfavorable atmosphere on the ground (Turang, AC, et al, 2015). Furthermore, Ayyub et al (2012) adding that Calcium has a role which is important in maintaining the quality of the fruit, preserving the integrity of the cells, and the growth of the fruit.

\section{CONCLUSION}

1. Provision of rice husk ash give the significant effect on plant growth on plant heigh and the number of leaves, the best dose is the provision of rice husk ash $50 \mathrm{~g} /$ plant 
JARES, Vol. 3 No. 1 March, 2018; p-ISSN: 2502-826X; e-ISSN: 2503-1163

Copyrights@ Balitar Islamic University, Blitar, Indonesia;

Http://jares.unisbablitar.web.id

2. Giving eggshell give the significant effect on plant yield which is the amount of red pepper productive branches, number of fruits per plant and the weight of the fruit crop, the best dosage $30 \mathrm{~g} /$ plant.

\section{REFERENCES}

Agustin, L., 1990, Nutrisi Tanaman, Rineka Cipta, Jakarta.

Ayyub, M. C., M. A. Pervez., M. R. Shaheen, M. I. Ashraf, M. W. Haider, S. Hussain, and N. Mahmood. 2012. Assessment of Various Growth and Yield Attributes of Tomato in Response to PreHarvest Apllications of Calcium Chloride. Pakistan Journal of Life and Social Science. 10(2) : 102-105.

Baharudin, R. 2016. Respon Pertumbuhan dan Hasil Tanaman Cabai (Capsicum annum L.) terhadap Pengurangan Dosis NPK 16:16:16 dengan Pemberian Pupuk Organik. Jurnal Dinamika Pertanian (XXXII): 2 . hal 115-124.

Dewi, ES, M Yusuf N dan Mursalin. 2016. Aplikasi Serbuk Cangkang Telur pada Sorgum (Sorghum bicolor L.). Jurnal Agrium Vol 13 (2) : 81-86

Gery D, Butcher, D.V.M. Ricahrd, Miles.2003. Concepts Of Eggshell Quality.Journal ternational IFASExtenion. Institute Of Food AndAgricultural Sciences. UniversityFlorida. Gainesville FL 32611.

Hardjowigeno, S. 2003. Ilmu Tanah. Akademik Pressindo. Jakarta

Kastono. 2005. Pengantar Ekologi. UGM. Yogyakarta

Kusuma, A.H, Munifatul Izzati dan Endang Septiningsih, 2013. Pengaruh Penambahan Arang dan Abu Sekam dengan Proporsi yang berbeda terhadap Permeabilitas dan Porositas Tanah Liat serta Pertumbuhan Kacang Hijau (Vigna radiate L.). Buletin Buletin Anatomi dan Fisiologi Volume $21(1): 1-9$.

Lingga, Pinus dan Marsono. 2008. Petunjuk Penggunaan Pupuk. Jakarta: Penebar Swadaya. Ha: 87.

Marita, M.M, 2013. Uji Efektivitas Berbagai Cangkang Telur terhadap Jamur Fusarium Oxysporum pada Berbagai Cangkang Telur pada Perkembangan Tanaman Tomat ( Solanum lycopersicum L.). http// Unej.ac.id/handle/123456789/2324. Diakses pada 28 Juni 2016.

Norhasanah, 2012. Respon Perumbuhan dan Hasil Tanaman Cabe Rawit (Capsicum frutescens Linn) Varietas Cakra Hijai terhadap Pemberian Au Sekam Padi pada Tanah Rawa Lebak. Jurnal Agro scientiae Vol 19 (1) : 1-5.

Noviansyah, B, dkk. 2015. Aplikasi Pupuk Organik Dari Campuran Limbah Cangkang Telur Dan Vetsin Dengan Penambahan Rendaman Kulit Bawang Merah Terhadap Pertumbuhan Tanaman Cabai Merah Keriting (Capsicum annum L) Var. Longum. Bioeksperimen (1) :1. Hal. 45-48. 
JARES, Vol. 3 No. 1 March, 2018; p-ISSN: 2502-826X; e-ISSN: 2503-1163

Copyrights@ Balitar Islamic University, Blitar, Indonesia;

Http://jares.unisbablitar.web.id

Nurjayanti, dkk.2012. Pemanfaatan Tepung Cangkang Telur sebagai Substitusi Kapur dan Kompos Keladi terhadap Pertumbuhan dan Hasil Cabai Merah pada Tanah Aluvial.Jurnal Sains Mahasiswa Pertanian Vol1.No1.Desember 2012 hal 16-21.

Septiawan, I.G. 2014. Kombinasi Arang Sekam Padi dan Pupuk Kompos Sebagai Bahan Pembenah Tanah Pada Budidaya Tanaman Jagung (Zea mays. L.) di Jatikerto. Fakultas Pertanian. Universitas Brawijaya. Malang

Syam, Z. Z , Amiruddin Kasim dan Musdalifah Nurdin, 2014. Pengaruh Serbuk Cangkang Telur Ayam terhadap Tinggi Tanaman Kamboja Jepang (Adenium obesum). e-Jibbiol vol 3 (3): 9-15

Tamtomo, F, Sri Rahayu dan Agus Suyanto, 2015. Pengaruh Aplikasi Kompos Jerami dan Abu Sekam padi terhadap Produksi dan Kadar Pati Ubijalar. Agrosains Vol 12 (2) : 1-7

Turang, A,C. dan Wowiling, J. 2015. Kegunaan Unsur-unsur bagi Tanaman. BPTP Sulawesi Utara. http://sulut.litbang.pertanian.go.id/ind/index.php?option=com_content\&view=article\&id=582\&It $\underline{\text { emid }=65}$. Diakses pada 12 januari 2018

Yulianti, C,E. 2011. Efek Pemanfaatan Abu Sekam sebagai Sumber Silika (Si) untuk Memperbaiki Kesuburan Tanah Sawah. Fakultas Pertanian Universitas Andalas. Skripsi 